\title{
Examining the Role of Engaging in Research Activities with Digital Technologies for Graduate Students' Success
}

\author{
https://doi.org/10.3991/ijet.v16i04.18045 \\ Hye Jeong Kim \\ Chung-Ang University, Seoul, Korea \\ Suyoun Lee $(\bowtie)$ \\ Pukyong National University, Pusan, Korea \\ creativethink1030@gmail.com
}

\begin{abstract}
This study aims to examine graduate students' academic experiences in conducting scientific research activities at graduate schools, which have been impacted by the use of information and communication technologies. They advance their experiences by taking courses, conducting research, assisting in the research of their advisors, and teaching through the adoption of digital technologies. The data were collected from graduate students who enrolled at five universities in metropolitan areas of South Korea. The results of the quantitative analysis in this study are based on the answers of 188 graduate students who responded via an online survey regarding their individual research activities and use of technology. Our results revealed that graduate students who engaged in research projects, courses involving research methods, and courses based on integrated technology use had significantly higher mean scores for the use of technology in scientific research activities.
\end{abstract}

Keywords-Technology use, academic performance, research practice, graduate students, research training program

\section{Introduction}

A myriad of technologies, such as search engines, statistics software, and collaboration tools, are increasingly being deployed to support graduate students' engagement with, and employment of, their academic research [1-3]. Technological advancements have influenced student practices and performance in graduate education [4]. One goal of graduate school is to produce independent scholars, experts, teachers, or researchers in the respective disciplines, as well as empower them to develop profound knowledge and skills [5]. The emergence of innovative technologies has undoubtedly provided new opportunities for students in higher education [4, 6-7]. The importance of preparing and training graduate students to leverage evolving information and communication technologies continues to grow in importance as it becomes increasingly woven into the essential aspects of student life in institutions offering higher education. 
Recently, graduate students in many degree programs are expected to devote significant time and effort toward coursework, research, and/or teaching with using digital technologies. Graduate students' research skills increasingly require the adoption of technology in their research practices [1-2]. In fact, the use of technological tools for conducting research is now considered a core competency. In order to deepen their knowledge and learn critical skills, graduate students currently find information and literature by using Internet search engines and online databases, manage their research literature via reference management tools, employ experiments and analyze results using tailored software, and communicate with their colleagues or professors electronically [8-9].

\section{Literature Review}

\subsection{Research skills and technologies}

Graduate students' research-mindedness is associated with skills regarding investigation, communication, analysis, and teamwork [10]. In order to enhance these skills in the context of student research-mindedness, they need to be developed by experiencing the underlying research processes. Wilson and O'Regan [11] constructed a conceptual model, entitled the Research Skill Development (RSD) framework, to help educators formulate pedagogies for the development of student research skills. The RSD framework consists of six facets of research processes, in which students:

- Embark and clarify on enquiry, thus determining a need for knowledge and understanding

- Find / generate necessary information and data using appropriate methodologies

- Evaluate information / data and the processes used to find/generate this information

- Organize the information collected and manage the research process

- Synthesize / apply / analyze new knowledge

- Communicate knowledge and understanding and the processes used to generate these advances, while also maintaining an awareness of any relevant ethical, social, and cultural issues [12-13].

The advancement of information and communication technology has assisted the research processes of researchers and students by strengthening each process through the adoption of appropriate technology. Professional researchers increasingly leverage technologies, such as information search tools, communication tools, conferencing systems, electronic journals, and literature management software $[9,14]$, reflecting their importance across different disciplines [15]. We discuss the role of information and communication technology (ICT) for research skills based on the RSD model (see Figure 1). 


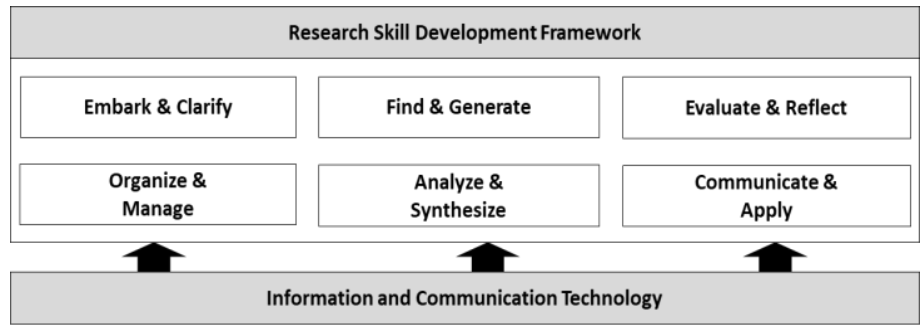

Fig. 1. The research skills development model [13] and information and communication technology

First, ICT supports the finding of information and generation of data through appropriate methodologies in the research process [16]. Information-seeking skills are frequently mentioned in the existing literature as key research competencies for graduate students [18-21]. Searching for information or literature represents a fundamental activity in a research project, but this process can prove challenging for students who lack fluency in searching for information [22]. Many graduate students might initiate an Internet search using a search engine to conduct their research and identify research topics, information, and any relevant literature when they begin a research activity or training [23]. Ackerson [24] proposed a model designed to guide graduate students during their search for relevant research literature; the model includes searching subject indexes, identifying review articles, searching for ancestors, searching for descendants, identifying key documents, and gauging current awareness. Further, Blummer et al. [18] reported that graduate students identify information needs as the following: to locate statements, generate relevant keywords, gain access to more specific materials, search database collections, download articles, and search for digitized books and online reports through the Internet. Thus, in order to foster responsible academic research using technology, it has been proven necessary to provide instruction and research training tailored to graduate students' needs regarding information searches and the management of these processes $[18,20]$.

Second, research processes also include analyzing information or data and putting it together to uncover new knowledge. Graduate students who perform research activities tend to use technologies to gather and analyze data, before then demonstrating their results [19]. These students are thus expected to improve their competency in data management and data analysis. Science, technology, engineering, and mathematics tend to rely on technology to perform research, such as identifying and searching databases, using specialized laboratory equipment, utilizing technology for data analysis, demonstrating data visualization, and maintaining processes and outcomes [21]. In addition, graduate education emphasizes a student's ability to plan, execute, and analyze their resulting data [25]. In social science fields, graduate students' selfefficiency is considered to be an important means of professional growth and development [26]. However, graduate students in social sciences often experience difficulty with statistics, even though the academic field requires students to possess competency in this area [26,27]. Thus, technologies are used to help graduate students learn 
how to handle data and statistics programs, as well as visualize the findings for their research projects.

Third, ICT supports the communication and application of their research, as well as responding to feedback from the research process. Communication skill is an essential aspect of research training. As a core component of every academic career, academic writing is required to disseminate an academician's work [28]. In order to question and articulate knowledge, writing is a fundamental process in the development of our research capacity [29]. Academic writing includes fundamental processes of research activities, such as formulating ideas, communicating with others, connecting ideas, synthesizing ideas, learning new ideas, and producing academic papers, and technologies can help perform these research activities more efficiently. Wood et al. [28] reported that regardless of the discipline, graduate students and faculties $(n=142)$ across various fields have addressed the advantages of using computers to write papers, such as the efficiency computers provided for editing (69.0\% of all respondents) and the quality of the appearance of the finished product (34.5\% of all respondents).

ICT also supports collaborations with other researchers, with teams often working together to obtain information, solve problems, obtain better ideas, manage projects, and share information [30-33]. The socialization of graduate students is the most important function of a university, which fundamentally aims to promote the formation of a society of individuals who can be relied upon to regulate their own behavior [34]. Collaboration with other researchers is recognized as a mediator of research productivity. According to Lee and Bozeman [30], the rise of the interdisciplinary, complex, and costly characteristics of modern science necessitates researchers' collaborative efforts because collaboration is a major factor in promoting and transmitting human capital. Indeed, research collaboration in science has been shown to have a positive effect on scientific productivity in that the degree of collaboration of the authors, combined with the level of research productivities, is proportional to the number of journal paper publications [30]. It is important that graduate students, particularly doctoral students, are presented with opportunities to interact with others within or beyond the campus [21]. There are differences in using technologies for collaboration among the various disciplines. This is due to the social norms of practice, the structure of knowledge, and the technological infrastructure in question [35-36].

\subsection{Engaging in research training}

Research training in graduate education falls between the boundaries of academic research cultures and discipline-specific research cultures [37]. Research training for graduate students, especially for those in the Arts and Humanities, "includes the values and practices informing the curriculum and pedagogies of training, the content of the courses, the conceptual basis for the legitimation of training, provision of symbolic meaning, shared aims and purposes, the use of resources such as information technology, and the social relations around training provision" (p. 156). In this view of using resources for research training, incorporating a technological approach within graduate education can be better emphasized to promote its increased effectiveness in graduate education. 
Different academic disciplines take tailored approaches toward developing the necessary research competencies of their graduate students. Parker [25] asserts that graduate programs in scientific disciplines focus on skills development and scientific discovery for their graduate students. The research competency of graduate students can be built through the following components: developing professional skills, acquiring a broad and deep knowledge of the discipline or interdisciplinary studies, clarifying thoughts, writing and speaking effectively, critically reading scientific literature, performing experiments, conceiving new insights, and identifying key issues for research. These skills can be aligned with the specific functional features of different supporting technologies.

Information and communication technology literacy for academic research in graduate schools tends to be taught either within graduate programs or courses, at on- and off-campus seminars or workshops, or by the faculty advisor [18,23,38-39]. Depending on the specific graduate program or course, research skills using information and communication technologies are normally taught through mandatory or optional participation. Different venues, such as learning centers or the libraries of each university, typically provide opportunities for students to enhance their research skills using the available technologies. However, graduate programs tend to not specify or describe the technologies that are aligned with the research activities involved in their coursework.

\subsection{The present research}

While a growing body of technologies that typically focus on a specific technology or domain are being employed by graduate students, one of the main motives of the present research is to amend the relative absence of previous research into how research activities at graduate schools have been impacted by the use of information and communication technologies. The present research is based on the assumption that graduate students' proficiency of technology use in scientific research activities is positively associated with the backgrounds and academic experiences of the students in question. As this is a piece of exploratory research, we need to understand what induces graduate students to utilize technologies for their scientific research activities. The results of the study will reveal evidence of the ways in which graduate schools can influence their students' experiences and research practices. In addition, this study also aims to investigate the relationship between graduate students' use of technology and individual factors regarding research practices. For this research, graduate students' gender and age are used as control variables in the analyses. This study was guided by two questions: (1) How proficiently do graduate students use technologies for scientific research activities and (2) Does students' attendance of courses related to research methods affect their technology proficiency in conducting research? By gaining a better understanding of how differences in students' characteristics influence their technology use in research activities, the quality of graduate programs in leveraging technologies for research can subsequently be improved. As such, effective programs designed to meet students' needs as they adopt technology for their research practices can help improve their academic performance. 


\section{Methods}

\subsection{Participants}

Of the 188 students, 91 were females $(48.4 \%)$ and 97 were males (51.6\%). Their ages ranged from 20 to 50 years, with $52.1 \%$ aged between 25 and 29 years. An overall $73.4 \%$ of students in the sample were enrolled in a Master's program, whereas 26.6\% were in enrolled in Doctoral programs or combined Master's and Doctoral programs. In terms of their academic disciplines, $30.3 \%$ were in engineering, $20.8 \%$ were in the natural sciences, and $48.9 \%$ were in social sciences.

\subsection{Data collection}

For this study, all of the surveyed students were graduate students enrolled at five private universities in metropolitan areas of South Korea. The data were collected as a part of a study on graduate students' educational experiences. Students were asked to participate voluntarily through an online survey developed by the authors of the study. They were contacted through their university staff and their campus email addresses via a link to an online survey hosted on SurveyMonkey.com, a web-based survey solution provider. Those who chose to participate completed the survey through this website. The survey was developed and disseminated to graduate students for a policy research study focused on coursework, research, and teaching. The data formed part of a large-scale study regarding graduate students' academic engagement. Students were asked to select the responses that appropriately expressed their experiences and knowledge. A total of 188 survey responses were used after collecting and cleaning the dataset.

\subsection{Measures}

The original survey was designed to investigate graduate students' academic life in terms of coursework, research, and teaching. In order to examine students' experiences in using digital technologies as a part of their research activities, technology items were added with respect to the extent to which graduate students are proficient. For this study, items were adapted regarding the following variables: background information (gender, age, education, full-time or part-time, and academic disciplines), academic experiences (coursework and technology integration in their respective courses), and research experience variables (their research project and the requirement of writing a thesis).

Research experience variables were employed to explore the determinants of technology use for research activities. Students were asked questions that centered on the registration of their research training course(s), their attendance of on- and off-campus research workshops and seminars, their participation in research projects, their work on thesis/dissertation, and their requirements regarding the thesis/dissertation in their program. 
The proficiency of digital technology use for research as a dependent variable was evaluated by asking graduate students the following: "How proficient are you in using technology in your research activities?" The items are focused on students' assessments regarding their level of proficiency in using the following digital technologies in scientific research activities: search engines (e.g., searching internal and external databases for academic purpose), literature management (e.g., Endnote), mathematics software (e.g., Matlab), statistics software (e.g., SPSS or SAS), spreadsheet software (e.g., Excel), word-processing software, graphic software, (cloud-based) collaboration software, and messaging software. These items were based on interviews with twelve graduate students and three graduate assistants; the interviews were designed to examine the patterns of technology use in independent or team-based research work. For the analyses, the possible choices for the questions were rated on a 4-point Likert-type scale: "very proficient" coded as 4, "proficient" coded as 3, "less proficient" coded as 2 , and "not proficient," coded as 1 .

\subsection{Measures}

Descriptive statistical analysis was conducted to examine the demographic characteristics of the sample. Data from the survey were analyzed using IBM SPSS 23.0. Demographic variables were included as previous findings indicated the impact of both gender and age as significant in relation to technology use [40-42]. Correlations were performed to examine the relationships between graduate student proficiency regarding technology use for research activities and taking courses that integrated technology. Graduate students' technology proficiency for research activities were compared by gender, age group, level of education, registration (full-time or parttime), and academic disciplines using a t-test and analysis of variance.

\section{$4 \quad$ Results}

\subsection{Technology use for research activities}

Data from 188 graduate students in the academic fields of engineering, science, and social science were analyzed for the study to assess each student's level of technology proficiency for research activities. In Table 1, search engines for research purposes were the most proficient form of technology for research $(\mathrm{M}=3.39, \mathrm{SD}=.76)$, while mathematics software produced the lowest mean score $(\mathrm{M}=1.66, \mathrm{SD}=1.06)$, below the median score of 1.00 . The respective levels of technology proficiency were as follows: Literature management software was $2.01(\mathrm{SD}=1.04)$, Mathematic software was $1.66(\mathrm{SD}=1.06)$, statistics software was $2.26(\mathrm{SD}=1.20)$, spreadsheet software was $3.40(\mathrm{SD}=.80)$, word-processing software was $3.73(\mathrm{SD}=.53)$, graphics software was $2.14(\mathrm{SD}=1.06)$, messaging software was $3.25(\mathrm{SD}=.88)$, and shared cloud storage was $2.37(\mathrm{SD}=1.15)$. In Table 1 , there were also statically significant differences in technology proficiency for research activities according to gender in the use of literature management software $(\mathrm{t}=3.16, \mathrm{p}<.01)$, mathematics software $(\mathrm{t}=$ - 
$3.55, \mathrm{p}<.01)$, statistics software $(\mathrm{t}=4.16, \mathrm{p}<.001)$, spreadsheet software $(\mathrm{t}=-2.23$, $\mathrm{p}<.05)$, and shared cloud storage $(\mathrm{t}=2.58, \mathrm{p}<.05)$. On the other hand, literature management software, word-processing software, graphics software, and messaging software did not show statistical differences. Literature management software (e.g., Endnote) tends to be supplied through the university library and is demonstrated to graduate students by the library staff as a core service. As many students lack previous experience in using library management software, they may opt to participate in more workshops or seminars on campus held by the library. This assessment can be explained by the tendency among female students to make greater use of university services to enhance their competencies and performance in academic work [43].

Table 1. Descriptive statistics of technology variables and gender difference

\begin{tabular}{|c|c|c|c|c|c|c|c|}
\hline \multirow{2}{*}{ Research Software } & \multicolumn{2}{|c|}{ Total $(n=175)$} & \multicolumn{2}{|c|}{ Female $(n=85)$} & \multicolumn{2}{|c|}{ Male $(n=90)$} & \multirow{2}{*}{$\begin{array}{l}\text { Gender } \\
\text { t-value }\end{array}$} \\
\hline & $M$ & $S D$ & $\boldsymbol{M}$ & $S D$ & $M$ & $S D$ & \\
\hline Search engines for research & 3.39 & .76 & 3.58 & .64 & 3.22 & .83 & $3.16^{* *}$ \\
\hline Literature management & 2.01 & 1.04 & 2.15 & 1.07 & 1.87 & 1.00 & 1.84 \\
\hline Mathematics & 1.66 & 1.06 & 1.38 & .84 & 1.92 & 1.17 & $-3.55 * *$ \\
\hline Statistics & 2.26 & 1.20 & 2.64 & 1.22 & 1.91 & 1.07 & $4.16^{* * * *}$ \\
\hline Spreadsheet & 3.40 & .80 & 3.26 & .91 & 3.53 & .67 & $-2.23 *$ \\
\hline Word-processing & 3.73 & .53 & 3.74 & .54 & 3.71 & .52 & .36 \\
\hline Graphics & 2.14 & 1.06 & 2.14 & 1.09 & 2.14 & 1.03 & -.02 \\
\hline Messaging & 3.25 & .88 & 3.30 & .89 & 3.20 & .86 & .76 \\
\hline Shared cloud storage & 2.37 & 1.15 & 2.60 & 1.13 & 2.16 & 1.14 & $2.58 *$ \\
\hline
\end{tabular}

Note: $* \mathrm{p}<0.05$. ** $\mathrm{p}<0.01 . * * * \mathrm{p}<0.001$.

\subsection{Graduation thesis or dissertation}

Table 2 shows the average proficiency of technology use for research activities perceived by graduate students. The students have been divided into two groups according to whether or not they were required to write a graduation thesis. Unexpectedly, most technologies did not show differences regarding technology proficiency for research activities according to this factor, with the exception of using search engines for research $(\mathrm{t}=2.55, \mathrm{p}<.05)$. 
Table 2. Graduation thesis and technology proficiency

\begin{tabular}{|c|c|c|c|c|c|}
\hline \multirow{3}{*}{ Research Software } & \multicolumn{5}{|c|}{ Graduation thesis $(n=179)$} \\
\hline & \multicolumn{2}{|c|}{ Yes $(n=149)$} & \multicolumn{2}{|c|}{ No $(n=30)$} & \multirow{2}{*}{ t-test } \\
\hline & $M$ & $S D$ & $M$ & $S D$ & \\
\hline Search engines for research & 3.46 & .71 & 3.07 & .96 & $2.55^{*}$ \\
\hline Literature management & 2.01 & 1.06 & 1.97 & .94 & .23 \\
\hline Mathematics & 1.71 & 1.10 & 1.41 & .78 & 1.70 \\
\hline Statistics & 2.30 & 1.21 & 2.07 & 1.16 & .95 \\
\hline Spreadsheet & 3.42 & .80 & 3.34 & .81 & .43 \\
\hline Word-processing & 3.74 & .51 & 3.66 & .61 & .78 \\
\hline Graphics & 2.17 & 1.06 & 2.00 & 1.07 & .79 \\
\hline Messaging & 3.23 & .88 & 3.32 & .86 & -.48 \\
\hline Shared cloud storage & 2.39 & 1.18 & 2.29 & 1.01 & .44 \\
\hline
\end{tabular}

Note. ${ }^{*} \mathrm{p}<0.05$

\subsection{Research method courses and technology proficiency}

In terms of participant experiences regarding the undertaking of research method courses (Table 3), the results from the descriptive analysis suggest that the participants reported the use of search engines for research $(\mathrm{M}=3.44, \mathrm{SD}=.69)$, literature management $(\mathrm{M}=2.16, \mathrm{SD}=1.12)$, mathematics software $(\mathrm{M}=1.61, \mathrm{SD}=1.05)$, statistics software $(\mathrm{M}=2.55, \mathrm{SD}=1.19)$, spreadsheet software $(\mathrm{M}=3.3, \mathrm{SD}=.9)$, wordprocessing software $(\mathrm{M}=3.72, \mathrm{SD}=.54)$, messaging software $(\mathrm{M}=3.34, \mathrm{SD}=.82)$, and shared cloud storage $(\mathrm{M}=2.52, \mathrm{SD}=1.19)$. However, the results show that three technologies for research, literature management software $(t=2.03, p<0.5)$, statistics software $(\mathrm{t}=3.21, \mathrm{p}<.01)$, and graphics software $(\mathrm{t}=-3.55, \mathrm{p}<.01)$, were statistically significant. We also noticed that research method courses did not seem to have an influence on the curriculum regarding various technologies for graduate students' research activities, except for literature management software and statistics software.

Table 3. Taking courses regarding research methods and technology proficiency

\begin{tabular}{|l|c|c|c|c|c|c|c|}
\hline \multirow{3}{*}{\multicolumn{1}{c|}{ Research Software }} & \multicolumn{7}{c|}{ Research method courses(n=179) } \\
\cline { 2 - 8 } & \multicolumn{3}{|c|}{ Yes } & \multicolumn{3}{c|}{$\boldsymbol{N o}$} & \multirow{2}{*}{$\boldsymbol{t}$-test } \\
\cline { 2 - 8 } & $\boldsymbol{M}$ & $\boldsymbol{S D}$ & $\boldsymbol{n}$ & $\boldsymbol{M}$ & $\boldsymbol{S D}$ & $\boldsymbol{n}$ & \\
\hline Search engines for research & 3.44 & .69 & 97 & 3.42 & .77 & 66 & .17 \\
\hline Literature management & 2.16 & 1.12 & 96 & 1.83 & .90 & 66 & $2.03^{*}$ \\
\hline Mathematics & 1.61 & 1.05 & 97 & 1.70 & 1.08 & 66 & -.52 \\
\hline Statistics & 2.55 & 1.19 & 97 & 1.95 & 1.13 & 66 & $3.21^{* *}$ \\
\hline Spreadsheet & 3.41 & .83 & 96 & 3.48 & .67 & 63 & -.59 \\
\hline Word-processing & 3.72 & .54 & 96 & 3.78 & .49 & 63 & -.71 \\
\hline Graphics & 1.93 & 1.01 & 97 & 2.52 & 1.07 & 66 & $-3.55^{* *}$ \\
\hline Messaging & 3.34 & .82 & 96 & 3.12 & .94 & 65 & 1.53 \\
\hline Shared cloud storage & 2.52 & 1.19 & 96 & 2.21 & 1.12 & 66 & 1.69 \\
\hline
\end{tabular}

Note. ${ }^{*} \mathrm{p}<0.05 . *{ }^{*} \mathrm{p}<0.01$ 


\subsection{Research project}

The group differences between graduate students who had experience in participating in previous research projects and students with no experience were examined. Interestingly, most technology proficiency was shown via high mean scores in the group who had participated in a research project (Table 4), while the results from the descriptive analysis suggested that the participants reported using search engines for research $(\mathrm{M}=3.56, \mathrm{SD}=.64)$, literature management $(\mathrm{M}=2.03, \mathrm{SD}=1.06)$, mathematics software $(\mathrm{M}=1.86, \mathrm{SD}=1.16)$, statistics software $(\mathrm{M}=2.35, \mathrm{SD}=1.28)$, spreadsheet software (M=3.65, $\mathrm{SD}=.6)$, word-processing software $(\mathrm{M}=3.63, \mathrm{SD}=.61)$, messaging software $(\mathrm{M}=3.34, \mathrm{SD}=.78)$, and shared cloud storage $(\mathrm{M}=2.36, \mathrm{SD}=1.17)$. The results show that five technologies for research produced statistically significant differences regarding whether the students had experience in participating in research project. These are as follows: Search engines for research $(t=3.12, p<0.1)$, mathematics software $(\mathrm{t}=2.91, \mathrm{p}<.01)$, spreadsheet software $(\mathrm{t}=4.39, \mathrm{p}<.001)$, word-processing software $(\mathrm{t}=2.15, \mathrm{p}<.05)$, and graphics software $(\mathrm{t}=2.95, \mathrm{p}<.01)$. The existing experience of graduate students showed meaningful results overall in that they seem to have practical knowledge and skills regarding how to use technologies for their research activities in the context of working with their colleagues and advisors.

Table 4. Experience in participating in research projects

\begin{tabular}{|c|c|c|c|c|c|}
\hline \multirow{3}{*}{ Research Software } & \multicolumn{5}{|c|}{ Research project $(n=179)$} \\
\hline & \multicolumn{2}{|c|}{ Yes $(n=99)$} & \multicolumn{2}{|c|}{ No $(n=80)$} & \multirow{2}{*}{ t-test } \\
\hline & $M$ & $S D$ & $M$ & $S D$ & \\
\hline Search engines for research & 3.56 & .64 & 3.19 & .85 & $3.12 * *$ \\
\hline Literature management & 2.03 & 1.06 & 1.97 & 1.03 & .36 \\
\hline Mathematics & 1.86 & 1.16 & 1.41 & .86 & $2.91 * *$ \\
\hline Statistics & 2.35 & 1.28 & 2.15 & 1.08 & 1.08 \\
\hline Spreadsheet & 3.65 & .60 & 3.12 & .91 & $4.39 * * *$ \\
\hline Word-processing & 3.81 & .45 & 3.63 & .61 & $2.15^{*}$ \\
\hline Graphics & 2.35 & 1.08 & 1.88 & .98 & $2.95 * *$ \\
\hline Messaging & 3.34 & .78 & 3.13 & .98 & 1.60 \\
\hline Shared cloud storage & 2.36 & 1.17 & 2.39 & 1.14 & -.16 \\
\hline
\end{tabular}

Note. $* \mathrm{p}<0.05 . * * \mathrm{p}<0.01 . * * \mathrm{p}<0.001$.

\section{$5 \quad$ Discussions and Conclusion}

This study aimed to explore the needs and directions required for effective research activities involving graduate students using digital technology. It set out to do this by exploring their perceptions of adopting technologies in the research activities of their disciplines. As an essential tool for research, digital technologies for supporting each phase of research (e.g., writing a thesis and the proceeding experiments) provide both opportunities and challenges for graduate students as novice researchers. As discussed above, graduate students' research-mindedness needs to be developed by experiencing the underlying research processes, including investigation, communication, analysis, 
and teamworking [10]. Thus, it is meaningful to discuss the training context and conditions required to raise graduate students' technology-integrated research mindedness. This study examined educational strategies designed to enhance graduate students' abilities in using digital technologies for their research practices. The findings show that graduate students had different levels of proficiency regarding technology usage in research practices by gender, academic disciplines, whether they require a thesis for graduation, whether they attend workshops for research methodologies, and participation in research projects.

First, the analyses of student background show that there are gender differences regarding student proficiencies in using technologies for research, such as using search engines for research, statistics software, spreadsheet software, and shared storages. Further, academic discipline also explained the differences between student proficiencies in technologies for research. However, students in all disciplines showed a high level of technology proficiency in using search engines for research.

Second, writing a graduation thesis made a difference in technology proficiency when using search engines for research. This result supports previous literature regarding frequent use of search engines (e.g., Wikipedia or Google scholars) by graduate students to conduct research [44-47]. Using search engines for research is associated with information-seeking skills, which form a core component of research in most disciplines and is activated during a research project [18-21]. Using search engines for research as a core skill can be enhanced through instruction and research training for graduate students who begin a research activity lacking the necessary experience and skills. Most pieces of research tend to use search engines (e.g., Google) at the beginning of the research project before then moving on to expert databases or library catalogues [48-49]. This implies that the use of search engines across all subjects is due to various and deeper explorations into research topics with practical forms of training.

Third, graduate students need to be provided the opportunity to enhance their research skills using technologies. The results show that the use of software for statistics and literature management presents higher values for technology proficiency in the group attending research method courses. Both forms of software are highly demanding for students who are in degree programs and are difficult to study how to use alone without receiving the necessary integration in adopting these platforms for research activities. Thus, it is important to integrate this training into the graduate curriculum of courses that focus on these research skills. This will augment the research experience more effectively, establishing a system that would far exceed the utility of a separate course in terms of efficacy [50]. Instead of a research methodology course, graduate students should also be afforded the opportunity to enhance their research skills using technologies in separate workshops designed to fill in the gaps in their research knowledge [38, 51]. Workshops for research methods can focus on narrow and specific research activity topics, such as searching for information and literature using databases in professional fields.

Finally, graduate students' experiences in participating in research projects seem to represent a meaningful activity in integrating technology for their research activities. The results showed that graduate students who had experiences of participating in 
research projects had higher average proficiency scores, even though there are notable differences between academic fields. One core activity in graduate programs is the requirement that graduate students engage in research activities within their respective disciplines, such as a thesis or research project. Research, as a systematic process of increasing knowledge, is often described as "seeking information through methodical processes to add to one's own body of knowledge and, hopefully, to that of others, by the discovery of non-trivial facts and insights" [52] (p.6). The findings of our study suggest that graduate students in scientific disciplines need to gain more experience in working on a project in order to use and learn technologies. This result implies that students can enhance technology use for research activities during these research projects. Research and educational activities for graduate students need to incorporate technologies that demonstrate the availability of effective and efficient tools or services in order to support their activities, especially due to variations based on academic context and discipline. For example, typical activities and corresponding tools for research include information-seeking behavior, documentation, communication with colleagues or professors, analyzing data, and visualization $[9,18,53]$. These skills can be actively adopted by engaging in authentic projects.

Information and communication technology plays a critical role in performing scientific research. This study examined graduate students' academic experiences in adopting technologies for scientific research activities, focusing on students' overall proficiency of using technologies designed for research activities, as well as relevant factors, such as gender, whether the student was required to submit a graduation thesis, taking research-method courses, and participating in other research projects. While engaged in research, various processes or tasks can be supported by functionoriented technologies using a framework for research skill development in graduate schools. The advancement of information and communication technologies over recent years reveals new potential in particular research processes. Even though technology adaptation for research is considered very helpful for graduate students as future scholars, a systematic approach designed to support research activities using technologies is not prevalent and has not been sustained in graduate school programs at a general level.

\section{Acknowledgement}

This work was supported by the Ministry of Education of the Republic of Korea and the National Research Foundation of Korea (NRF-2019S1A5B5A07111489).

\section{$7 \quad$ References}

[1] Click, A. B. (2018). International graduate students in the United States: Research processes and challenges. Library \& Information Science Research, 40(2), 153-162. https://doi. org/10.1016/j.lisr.2018.05.004 
[2] Gonulal, T., Loewen, S., \& Plonsky, L. (2017). The development of statistical literacy in applied linguistics graduate students. ITL-International Journal of Applied Linguistics, 168(1), 4-32. https://doi.org/10.1075/itl.168.1.01gon

[3] Romero-Hall, E. (2017). Posting, sharing, networking, and connecting: Use of social media content by graduate students. TechTrends, 61(6), 580-588. https://doi.org/10.1007/s11 $\underline{528-017-0173-5}$

[4] Tamim, R. M., Lowerison, G., Schmid, R. F., Bernard, R. M., \& Abrami, P. C. (2011). A multi-year investigation of the relationship between pedagogy, computer use and course effectiveness in postsecondary education. Journal of Computing in Higher Education, 23(1), 1-14. https://doi.org/10.1007/s12528-010-9041-4

[5] Blaj-Ward, L. (2011). Skills versus pedagogy? Doctoral research training in the UK Arts and Humanities. Higher Education Research \& Development, 30(6), 697-708. https://doi. org/10.1080/07294360.2010.535507

[6] Collins, A., \& Halverson, R. (2009). Rethinking education in the age of technology: The digital revolution and schooling in America. New York, NY: Teachers College Press.

[7] Islam, M. A., \& Tsuji, K. (2010). Assessing information literacy competency of information science and library management graduate students of Dhaka University. IFLA Journal, 36(4), 300-316. https://doi.org/10.1177/0340035210388243

[8] Pouratashi, M., \& Rezvanfar, A. (2010). Analysis of factors influencing application of ICT by agricultural graduate students. Journal of the American Society for Information Science and Technology, 61(1), 81-87. https://doi.org/10.1002/asi.21230

[9] Tingling, P., Parent, M., \& Wade, M. (2003). Extending the capabilities of Internet-based research: Lessons from the field. Internet Research, 13(3), 223-235. https://doi.org/10.11 $\underline{08 / 10662240310478231}$

[10] Brew, A. (2003). Teaching and research: New relationships and their implications for inquiry-based teaching and learning in higher education. Higher Education Research \& Development, 22(1), 3-18. https://doi.org/10.1080/0729436032000056571

[11] Wilson, T. D. (1999). Models in information behaviour research. Journal of Documentation, 55(3), 249-270.

[12] Willison, J., \& Buisman-Pijlman, F. (2016). PhD prepared: research skill development across the undergraduate years. International Journal for Researcher Development, 17(1), 63-68. https://doi.org/10.1108/ijrd-07-2015-0018

[13] Willison, J., \& O'Regan, K. (2007). Commonly known, commonly not known, totally unknown: a framework for students becoming researchers. Higher Education Research \& Development, 26(4), 393-409. https://doi.org/10.1080/07294360701658609

[14] Bakkabulindi, F. E. (2011). Individual characteristics as correlates of use of ICT in Makerere University. International Journal of Computing and ICT Research, 5(2), 38-45.

[15] Steur, J. M., Jansen, E. P. W. A., \& Hofman, W. H. A. (2012). Graduateness: An empirical examination of the formative function of university education. Higher Education, 64(6), 861-874. https://doi.org/10.1007/s10734-012-9533-4

[16] Ain, C. T., Sabir, F., \& Willison, J. (2019). Research skills that men and women developed at university and then used in workplaces. Studies in Higher Education, 44(12), 23462358. https://doi.org/10.1080/03075079.2018.1496412

[17] Blummer, B., Watulak, S. L., \& Kenton, J. (2012). The research experience for education graduate students: A phenomenographic study. Internet Reference Services Quarterly, 17(3-4), 117-146. https://doi.org/10.1080/10875301.2012.747462

[18] Blummer, B., Watulak, S. L., \& Kenton, J. (2012). The research experience for education graduate students: A phenomenographic study. Internet Reference Services Quarterly, 17(3-4), 117-146. https://doi.org/10.1080/10875301.2012.747462 
[19] Bright, A., Linke, E. C., Hurlbert, T., Clair, G. S., George, C., \& Stein, J. (2005). Scholarly use of information: Graduate students' information seeking behaviour. Information Research, 11(4), 13. Retrieved from http://informationr.net/ir/11-4/paper272.html

[20] Earp, V. (2008). Information source preferences of education graduate students. Behavioral \& Social Sciences Librarian, 27(2), 73-91. https://doi.org/10.1080/01639260802194974

[21] Mowbray, S., \& Halse, C. (2010). The purpose of the PhD: Theorising the skills acquired by students. Higher Education Research \& Development, 29(6), 653-664. https://doi.org/ $10.1080 / 07294360.2010 .487199$

[22] Pedró, F. (2010). ICT and Postgraduate Education, In T. Kerry (Ed.), Meeting the challenges of change in postgraduate education (pp. 105-121), Symposium Books, London/New York.

[23] Hoffmann, K., Antwi-Nsiah, F., Feng, V., \& Stanley, M. (2008). Library research skills: A needs assessment for graduate student workshops. Issues in Science and Technology Librarianship, 53. Retrieved from http://www.istl.org/08-winter/refereed1.html

[24] Ackerson, L. G. (1996). Basing reference service on scientific communication: Toward a more effective model for science graduate students. $R Q, 36(2), 248-260$.

[25] Parker, R. (2012). Skill development in graduate education. Molecular Cell, 46(4), 377381.

[26] Perepiczka, M., Chandler, N., \& Becerra, M. (2011). Relationship between graduate students' statistics self-efficacy, statistics anxiety, attitude toward statistics, and social support. The Professional Counselor: Research and Practice, 1(2), 99-108. https://doi.org/10. 15241/mpa.1.2.99

[27] Berk, R. A., \& Nanda, J. P. (1998). Effects of jocular instructional methods on attitudes, anxiety, and achievement in statistics courses. Humor, 11, 383-410. https://doi.org/10.15 15/humr.1998.11.4.383

[28] Wood, E., Willoughby, T., Specht, J., \& Porter, L. (2002). An examination of how a crosssection of academics use computer technology when writing academic papers. Computers \& Education, 38(1), 287-301. https://doi.org/10.1016/s0360-1315(01)00071-9

[29] Ryan, M. M., Yeung, R. S., Bass, M., Kapil, M., Slater, S., \& Creedon, K. (2012). Developing research capacity among graduate students in an interdisciplinary environment. Higher Education Research \& Development, 31(4), 557-569. https://doi.org/10.1080/072 $\underline{94360.2011 .653956}$

[30] Lee, S., \& Bozeman, B. (2005). The impact of research collaboration on scientific productivity. Social Studies of Science, 35(5), 673-702.

[31] Lew, S. L., \& Lau, S. H. (2020). An empirical study of students' intention to use cloud elearning in higher education. International Journal of Emerging Technologies in Learning (iJET), 15(09), 19-38. https://doi.org/10.3991/ijet.v15i09.11867

[32] McLoughlin, C., \& Luca, J. (2002). A learner-centered approach to developing team skills through Webbased learning and assessment. British Journal of Educational Technology, 33(5), 571-582 https://doi.org/10.1111/1467-8535.00292

[33] Nonthamand, N., \& Na-Songkhla, J. (2018). The correlation of open learning, collaboration, learning tools, and creative problem solving by graduate students in Thailand. International Journal of Emerging Technologies in Learning (iJET), 13(09), 280-289. https:// doi.org/10.3991/ijet.v13i09.7835

[34] Hindess, B. (1995). Great expectations: freedom and authority in the idea of a modern university. Oxford Literary Review, 17(1-2), 29-50. https://doi.org/10.3366/olr.1995.004

[35] Hara, N., Solomon, P., Kim, S. L., \& Sonnenwald, D. H. (2003). An emerging view of scientific collaboration: Scientists' perspectives on collaboration and factors that impact col- 
laboration. Journal of the American Society for Information Science and Technology, 54(10), 952-965. https://doi.org/10.1002/asi.10291

[36] Walsh, J. P., \& Bayma, T. (1996). Computer networks and scientific work. Social Studies of Science, 26(4), 661-703. https://doi.org/10.1177/030631296026003006

[37] Deem, R., \& Brehony, K. (2000). Doctoral students' access to research cultures are some more unequal than others? Studies in Higher Education, 25(2), 149-165. https://doi.org/10. 1080/713696138

[38] Fong, B. L., \& Hansen, D. B. (2012). Engaging research groups: Rethinking information literacy for graduate students. Issues in Science and Technology Librarianship. Retrieved from http://www.istl.org/12-fall/refereed2.html

[39] Franken, M. (2012). Re-situation challenges for international students 'becoming' researchers. Higher Education, 64(6), 845-859. https://doi.org/10.1007/s10734-012-9532-5

[40] Cooper, J., \& Weaver, K. D. (2003). Gender and computers: Understanding the digital divide. Mahwah, NJ: Lawrence Erlbaum.

[41] DiMaggio, P., Hargittai, E., Celeste, C., \& Shafer, S. (2004). Digital inequality: From unequal access to differentiated use. In K. Neckerman (Ed.), Social inequality (pp. 355-400). New York: Russell Sage Foundation.

[42] Hargittai, E. (2008). The digital reproduction of inequality. In D. Grusky (Ed.), Social stratification (pp. 936-944). Boulder, CO: Westview Press.

[43] Grebennikov, L., \& Skaines, I. (2009). Gender and higher education experience: A case study. Higher Education Research \& Development, 28(1), 71-84. https://doi.org/10.1080/ $\underline{07294360802444370}$

[44] Brophy, J., \& Bawden, D. (2005). Is Google enough? Comparison of an internet search engine with academic library resources. Aslib Proceedings, 57(6), 498-512. https://doi.org/ $\underline{10.1108 / 00012530510634235}$

[45] Liyana, S., \& Noorhidawati, A. (2014). How graduate students seek for information: Convenience or guaranteed result? Malaysian Journal of Library \& Information Science, $19(2), 1-15$.

[46] Rowlands, I, \& Nicholas, D. (2008). Understanding information behavior: How do students and faculty find books? The Journal of Academic Librarianship, 34, 3-15. https:// doi.org/10.1016/j.acalib.2007.11.005

[47] Wu, M., \& Chen, S. (2010). The impact of electronic resources on humanities graduate student theses. Online Information Review, 34(3), 457-472. https://doi.org/10.1108/14684 $\underline{521011054071}$

[48] Connaway, L. S., Radford, M. L., Dickey, T. J., Williams, J. D., \& Confer, P. (2008). Sensemaking and synchronicity: Information-seeking behaviors of Millennials and Baby Boomers. Libri, 58(2), 123-135. https://doi.org/10.1515/libr.2008.014

[49] Pang, L. (2020). Teaching Mode of Library Information Literacy Course Based on Hierarchical Embedded Service. International Journal of Emerging Technologies in Learning (iJET), 15(10), 27-41. https://doi.org/10.3991/ijet.v15i10.13995

[50] Lee, W. M., \& Wiggins, G. (1998). Alternative methods for teaching chemical information to undergraduates. Science \& Technology Libraries, 16(3-4), 31-43. https://doi.org/10.13 $\underline{00 / j 122 v 16 n 03 \_03}$

[51] Fong, B. L., Wang, M., White, K., \& Tipton, R. (2016). Assessing and serving the workshop needs of graduate students. The Journal of Academic Librarianship, 42(5), 569-580. https://doi.org/10.1016/j.acalib.2016.06.003

[52] Howard, K., \& Sharp, J. (2002). The management of student research project (3rd ed). Routledge. 
[53] Rogers, D. L. (2000). A paradigm shift: Technology integration for higher education in the new millennium. Educational Technology Review, 1(13), 19-33.

\section{Authors}

Hye Jeong Kim is an assistant professor in Graduate School of Education at Chung-Ang University in Republic of Korea. Her research interest is on technology integration in education, digital inclusion, educational informatics, and teacher professional development.

Suyon Lee works as a lecturer at Pukyong National University in Republic of Korea. Her current research interests include computational thinking of young children, digital literacy, and STEAM education.

Article submitted 2020-08-25. Resubmitted 2020-10-20. Final acceptance 2020-10-24. Final version published as submitted by the authors. 